\title{
性腺摘除によるアンギオテンシン変換酵素阻害薬の 降圧作用抑制効果と中枢レニンの役割
}

\author{
聖マリアンナ医科大学 薬理学教室 \\ (主任：平井正直教授） \\ 熊 井 俊 夫

\section{Gonadectomy - induced Reduction of Antihypertensive Action of Angiotensin Converting Enzyme Inhibitor and its Role of Central Renin Activity in Spontaneously Hypertensive Rats} \\ Toshio KUMAI
}

Department of Pharmacology, St. Marianna University School of Medicine, Kawasaki, Japan

\begin{abstract}
Gonadectomy induced a significant retardation of systolic blood pressure (BP) in male and female spontaneously hypertensive rats (SHR). Captopril $(5 \mathrm{mg} / \mathrm{kg}$, i.p.), an angiotensin converting enzyme (ACE) inhibitor, significantly decreased BP in all groups, except that the antihypertensive action was significantly inhibited by gonadectomy in both sexes. The plasma ACE activity was increased in orchiectomized males, but this effect did not appear in females. Neither plasma renin activity nor its concentration were changed by gonadectomy in either sex. Aorta ACE activity was not changed by gonadectomy in either sex, while the renin activity was increased only in gonadectomized females. Diencephalon $\mathrm{ACE}$ activity was not changed by gonadectomy in either sex, but the renin activity was decreased in these groups. These results suggested that the decrease of BP by gonadectomy in both sexes SHR was closely related to the decrease of renin activity in diencephalon by androgen deprivation with gonadectomy.
\end{abstract}

Key words : Gonadectomy, Brain, Renin, Blood pressure, Angiotensin converting enzyme inhibitor

\section{緒言}

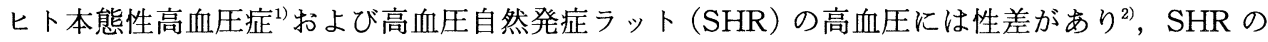
雄血圧はアンドロゲンの存在で, 雌血圧はエストロゲンの存在で, 高值を示すことを報告した ${ }^{34)}$ 。 血圧調節に脳内のアンギオテンシンと交感神経系が重要な働きをしていることは良く知られている 5)6)。私共はアンドロゲンが pre synapse のカテコールアミン (CA) 合成と放出を促進し，エストロ 
ゲンが post synaptic $\alpha$-receptor 感受性を亢進させることを報告し，これらの性ホルモンが交感 神経系に促進的効果を持つことを証明した7)。

しかし，レニンーアンギオテンシン（R-A) 系に対する性ホルモンの作用において，エストロゲ ンの血漿レニン活性 (PRA) やアンギオテンシンII（A II）に対する作用は見解が一致していない）。 最近, R-A 系が末梢だけでなく脳内の中枢性血圧調節系に促進的役割を果たしていることが報告 された9)。脳内の R-A 系は第3脳室や subfornical organ (SFO) に豊富であり, 血圧調節中枢とし て視床下部の重要性が指摘されている ${ }^{10)}$ 。今回, 末梢及び脳内の R-A 系に対する性ホルモンの役 割と血圧との関係を明らかにするために去勢による末梢および視床下部を含む間脳内のレニン活性 の変動を調ベ, 性ホルモンの役割, 機序を明らかにした。なお, アンギオテンシン変換酵素 (ACE) 活性についても合わせて検討を加えた。

\section{材 料と方 法}

\section{1. 実験動物}

Wistar 京都ラット (WKY) 由来の雌雄 SHR（57週齢）を用いた。動物は恒温恒湿 $\left(23 \pm 1{ }^{\circ} \mathrm{C}, 55\right.$ $\pm 5 \%)$, 人工照明 (06:00-18:00) 下の本学, 中央実験動物飼育管理研究施設内でアイソラックで飼 育した。動物は4週齢に雄はエーテル麻酔下, 経陰囊法で精巣を摘出, 雌はペントバルビタール麻 酔下, 開腹し卵巣を摘出した。精巣および卵巣摘出群はそれぞれ5匹ずつ, intact (Int) 群はそれ ぞれ10匹ずつ，合計30匹用いた。

\section{2. 血圧測定}

血圧は tail-cuff 法（理研開発 PS-100）により尾動脈収縮期血圧を非観血的に測定した。薬物 は $\mathrm{ACE}$ 阻害薬のカプトプリル（5mg/ kg, i. p. 三共）を Int 群, 性腺摘除群に投与し, 投与後の 血圧の変動を記録した。

\section{3. 組織調製法}

動物をペントバルビタール麻酔下, 両側腎動静脈を結紮し, 断頭直後, 頝部血液を採血し, 放血 致死後, 血漿を分取, ACE 活性, PRA と血漿レニン濃度 (PRC) を測定した。大動脈は Mizuno ら ${ }^{111}$ の方法に準じて調製した。即ち, 脂肪除去後 $2 \times 2 \mathrm{~mm}$ にミンスし, 10倍量の $0.25 \mathrm{M}$ sucrose 溶 液を加え，ホモジナイズし，ACE 活性，レニン活性測定に用いた。脳は Glowinski とIversen ${ }^{12)}$ の方法に準じ, 間脳を分切採取した。組織を10倍量の緩衝液 $(0.1 \mathrm{M} \mathrm{NaCl}, 2 \mathrm{mM}$ phenylmethylsulfonyl fluoride; PMSF, 0.05M Tris- $\mathrm{HCl}, \mathrm{pH} 7.40)$ 中でホモジナイズし, ACE 活性, レニン活 性測定に用いた。

\section{PRA 測定法}

血漿0.2ml, $1 \%$ PMSF $0.01 \mathrm{ml}, 0.05 \mathrm{M}$ リン酸緩衝液 (pH6.00) 0.02ml を加穴て $37^{\circ} \mathrm{C}, 90$ 分間イ ソキュベーションした。産生されたアンギオテンシン I (A I ) を radioimmunoassay（RIA） （レニン活性測定キット；固相法，ミドリ十字）で定量することによりレニン活性を測定した。

\section{PRC 測定法}

血漿 $0.05 \mathrm{ml}, レ$ レ基質血漿（両側腎臓摘出ラット 24 時間後の血漿） $0.2 \mathrm{ml}, 1 \% \mathrm{PMSF} 0.01 \mathrm{ml}$, $0.05 \mathrm{M}$ リン酸緩衝液 $(\mathrm{pH} 6.00) 0.03 \mathrm{ml}$ を加えて $37^{\circ} \mathrm{C}, 90$ 分間インキュベーションし, 産生された AI をIA で定量することによりレニン活性を測定した。 


\section{6. 組織レニン活性測定法}

上記 $3 . の$ 粗ホモジネートを $400 \times \mathrm{g}, 4^{\circ} \mathrm{C}, 15$ 分間遠心分離し, その上清を $20,000 \times \mathrm{g}, 4{ }^{\circ} \mathrm{C}, 15$ 分 間遠心分離し，沈渣を用いた。このレニンを多く含む沈渣 ${ }^{13}$ を上記 3. の緩衝液で再懸濁し, $-70^{\circ} \mathrm{C}$ で冷凍保存した。溶解した懸濁液, $200 \mu 1$ をアッセイ溶液 (10mM EDTA, 2mM PMSF, 0.05M

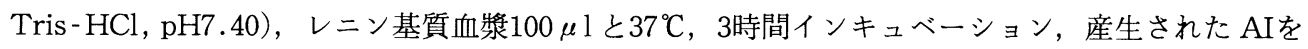
RIA で定量して，レニン活性を測定した。なお, インキュベーションはレニン以外のプロテアー ゼの影響を除外するため, pH7.40で行なった ${ }^{14)}$ 。

\section{7. レニン活性測定法}

上記で調製したサンプルおよびスタンダード $\mathrm{AI}$ 溶液 $0.05 \mathrm{ml},{ }^{125} \mathrm{I}-\mathrm{AI}$ 溶液 $0.5 \mathrm{ml}$ を $\mathrm{AI}$ 抗体結合 試験管に入れ, 混和した。その後, 室温 $\left(19-25^{\circ} \mathrm{C}\right)$ ， 18時間インキュベーションし, 内容液を吸 引除去後, 試験管内の ${ }^{125} I$ を測定した。

\section{ACE 活性測定法}

ACE 活性は ACE 活性測定キット（ベーリンガーマンハイム山之内）で測定した。上記3.の粗 ホモジネートを $400 \times \mathrm{g}, 4^{\circ} \mathrm{C}, 15$ 分間遠心分離し, 上清に $0.2 \%$ Triton X-100を加光, $12,000 \times \mathrm{g}$, $4{ }^{\circ} \mathrm{C}, 30$ 分間遠心分離した。上清或は血漿 $10 \mu 1$ を基質溶液（50mM Hepes 緩衝液, $300 \mathrm{mM} \mathrm{NaCl}$, $400 \mathrm{mM} \mathrm{Na}_{2} \mathrm{SO}_{4}, 30 \mathrm{mM}$ hippuryl-glycyl-glycine;pH8.00） $100 \mu 1$ と37 $7^{\circ} \mathrm{C} ３ 0$ 分間インキュベーショ ンした。反応を $\mathrm{Na}_{2} \mathrm{WO}_{4}(100 \mathrm{~g} / \mathrm{l}) 100 \mu \mathrm{l}$ で停止させ, 続いて, $0.33 \mathrm{M} \mathrm{H}_{2} \mathrm{SO}_{4} 100 \mu 1, \mathrm{H}_{2} \mathrm{O} 1 \mathrm{ml}$ を加 えた。混和後, $2,000 \times \mathrm{g}, 10$ 分間遠心分離し, 上清 $750 \mu \mathrm{l}$ を分取, $100 \mathrm{mM}$ ホウ酸緩衝液 $1 \mathrm{ml}$, $60 \mathrm{mM} 2,4,6$ - trinitrobenzensulfonic acid $50 \mu 1$ を加之, 混和後, $37^{\circ} \mathrm{C}, 15$ 分間インキュベーショ ンし，420nm で吸光度を測定した（日立分光光度計124）。蛋白定量は Lowry 法占で行なった。

\section{9. 検定法}

結果は平均值士標準誤差にて表示し, 有意差検定は student の $\mathrm{t}$ - test で行なった。有意差は危 険率5\%以下を有意差ありとした。

\section{実 験 結 果}

\section{1. カプトプリルの降圧効果に及ぼす雌雄 SHR 性腺摘除の影響(Fig. 1)}

カプトプリル投与前血圧は雄 Int 群 $(193.8 \pm 2.57 \mathrm{mmHg})$ に比し雄去勢群 $(168.3 \pm 2.57 \mathrm{mmHg})$, 及び雌Int 群 $(171.0 \pm 1.75 \mathrm{mmHg})$ がそれぞれ有意低值 $(\mathrm{p}<0.01)$ を示した。また, 雌 Int 群に 比し卵巣摘出群 $(155.9 \pm 1.82 \mathrm{mmHg})$ が有意低值 $(\mathrm{p}<0.01)$ を示した。カプトプリル投与により 各群共, 血圧は有意 $(\mathrm{p}<0.01)$ に低下した。カプトプリル投与による血圧低下の程度 $(\triangle \mathrm{BP})$ は 雄 Int 群 $(24.8 \pm 3.33 \mathrm{mmHg})$ に比し雄去勢群 $(12.3 \pm 1.44 \mathrm{mmHg})$ が有意低值 $(\mathrm{p}<0.05)$ を, 雌 Int 群 $(19.4 \pm 3.17 \mathrm{mmHg})$ に比し卵巣摘出群 $(13.7 \pm 1.78 \mathrm{mmHg})$ が低值傾向を示した。

\section{2. 血漿中 ACE 活性, PRA および PRC に及ぼす雌雄 SHR 性腺摘除の影響(Table. 1)}

血漿中 ACE 活性は性腺摘除の影響および性差が認められなかった。PRA および PRC は雄 Int 群が雌Int 群に比し有意低值 $(\mathrm{p}<0.05)$ を示した。しかし，雌雄共に性腺摘除の影響は認められな かった。

\section{3. 大動脈中 ACE およびレニン活性に及ぼす雌雄 SHR 性腺摘除の影響 (Table. 2)}

大動脈中 $\mathrm{ACE}$ 活性は性腺摘除の影響及び性差が認められなかった。大動脈中レニン活性は卵巣 摘出群が雌 Int 群に比し有意高值 $(\mathrm{p}<0.05)$ を示したが，雄は去勢の影響が認められず，また， Int群に性差は認められなかった。 


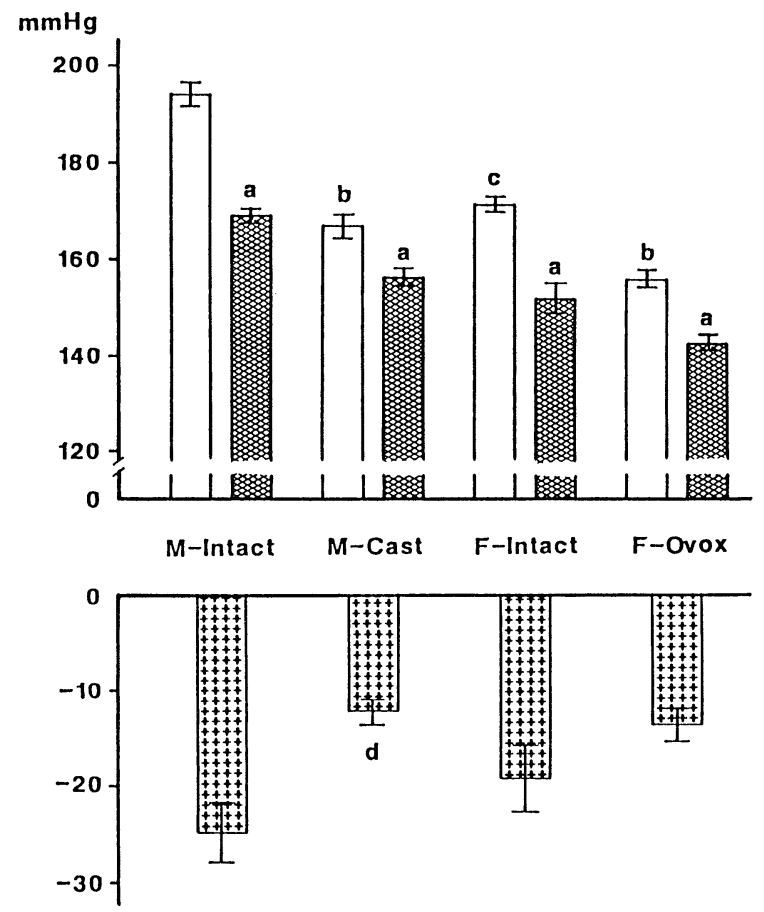

\section{$\Delta \mathrm{mmHg}$}

Fig. 1 Change of systolic blood pressure (BP) following captopril $(5 \mathrm{mg} / \mathrm{kg}$, i.p.) administration in intact and gonadectomized male and female. Values of control BP (open-bar), captopril administration BP (grid-bar) and their $\triangle B P$ (patch-bar) were illustrated in identical to groups. The values expressed with mean $\pm \mathrm{SE}$.

a: Significantly different from control BP. $(p<0.01)$

b: Significantly different from intact BP. $(p<0.01)$

c: Significantly different from intact male BP. $(\mathrm{p}<0.01)$

$\mathrm{d}$ : Significantly different from intact $\triangle \mathrm{BP} .(\mathrm{p}<0.05)$

Table. 1 The effects of gonadectomy in both sexes on plasma ACE activity, PRA and PRC.

\begin{tabular}{lccc}
\hline & $\begin{array}{c}\text { Plasma ACE activity } \\
(\mathrm{mU} / \mathrm{ml})\end{array}$ & $\begin{array}{c}\text { PRA } \\
(\mathrm{ng} \mathrm{A} \mathrm{I} / \mathrm{ml} / \mathrm{hr})\end{array}$ & $\begin{array}{c}\text { PRC } \\
(\mathrm{ng} \mathrm{A} \mathrm{I} / \mathrm{ml} / \mathrm{hr})\end{array}$ \\
\hline Male Intact & $391.7 \pm 58.47$ & $6.008 \pm 1.1887$ & $22.979 \pm 2.6357$ \\
Male Cast & $396.8 \pm 49.99$ & $7.439 \pm 2.1510$ & $32.195 \pm 6.5469$ \\
Female Intact & $318.1 \pm 32.85$ & $20.584 \pm 6.3776 \mathrm{a}$ & $98.343 \pm 27.736 \mathrm{a}$ \\
Female Ovox & $565.0 \pm 76.32$ & $16.994 \pm 0.6265 \mathrm{a}$ & $70.711 \pm 7.8421 \mathrm{a}$ \\
\hline
\end{tabular}

The values represent the mean $\pm \mathrm{SE}$ a: significant difference $(\mathrm{p}<0.05)$ from

male. Cast: castration. Ovox: ovariectomy 
Table. 2 The effects of gonadectomy in both sexes on aorta ACE activity and renin activity.

\begin{tabular}{lcc}
\hline & $\begin{array}{c}\text { Aorta ACE activity } \\
\text { (mU/mg protein) }\end{array}$ & $\begin{array}{c}\text { Aorta renin activity } \\
\text { ( ng A I /mg protein/hr) }\end{array}$ \\
\hline Male Intact & $52.3 \pm 9.03$ & $4.20 \pm 0.562$ \\
Male Cast & $49.6 \pm 6.44$ & $4.26 \pm 0.880$ \\
Female Intact & $46.0 \pm 3.78$ & $4.78 \pm 0.193$ \\
Female Ovox & $55.7 \pm 6.37$ & $5.94 \pm 0.395 \mathrm{a}$ \\
\hline
\end{tabular}

The values represent the mean \pm SE a: significant difference $(p<0.05)$ from male. Cast: castration. Ovox: ovariectomy

Table. 3 The effects of gonadectomy in both sexes on diencephalon ACE activity and renin activity.

\begin{tabular}{lcc}
\hline & $\begin{array}{c}\text { Diencephalon ACE activity } \\
\text { (mU/mg protein) }\end{array}$ & $\begin{array}{c}\text { Diencephalon renin activity } \\
\text { ( ng A I /mg protein/hr) }\end{array}$ \\
\hline Male Intact & $83.0 \pm 11.51$ & $1.17 \pm 0.164$ \\
Male Cast & $108.0 \pm 28.52$ & $0.50 \pm 0.233 \mathrm{a}$ \\
Female Intact & $81.7 \pm 24.59$ & $1.02 \pm 0.175$ \\
Female Ovox & $77.1 \pm 55.64$ & $0.58 \pm 0.119$ \\
\hline
\end{tabular}

The values represent the mean $\pm \mathrm{SE}$ a: significant difference $(\mathrm{p}<0.05)$ from male. Cast: castration. Ovox: ovariectomy

\section{4. 間脳中 ACE 及びレニン活性に及ぼす雌雄 SHR 性腺摘除の影響(Table. 3)}

間脳 $\mathrm{ACE}$ 活性は性腺摘除の影響及び性差が認められなかった。一方, 間脳レニン活性は雄 Int 群に比し雄去勢群が有意低值 $(\mathrm{p}<0.05)$ を, 雌Int 群に比し卵巣摘出群がそれぞれ低值傾向を示し た。しかし，Int群に性差は認められなかった。

\section{考察}

今回，雌雄 SHR を性腺摘除すると高血圧が有意阻害された。この結果は私共が以前に報告した 結果と一致する ${ }^{2}$ 。Chen と Meng は雄去勢は SHR の高血圧を有意阻害するが，卵巣摘出は，4週 齢摘出後 22 週齢までSHR の高血圧に影響を与えないことを報告している ${ }^{16)}$ 。性腺摘除の高血圧阻 害効果は雄よりも雌で小さく, 雌では効果発現にも時間を要する2)。このため, 雌での卵巣摘出に よる高血圧阻害効果を検討するには Chen と Meng の実験期間が短かった可能性が考えられる。

雌雄性腺摘除は ACE 阻害薬であるカプトプリルの降圧効果を抑制した。これは腎性高血圧モデ ルである $2 \mathrm{~K} 1 \mathrm{C}$ 高血圧ラットに扔いて雄を去勢するとカプトプリルの降圧効果を抑制したこと ${ }^{17)}$ 一致した。この結果は, 雄でアンドロゲンがカプトプリルの降圧機序に対し促進効果を持つことを 示している。更に雌 SHR にエストラジオールを投与するとカプトプリルの降圧効果が促進し，こ のことからエストロゲンもカプトプリルの降圧機序に対し促進効果を持つことを報告した文。これ らの事から, 雌雄性腺摘除による SHR 高血圧阻害効果の一因として性ホルモン（雄ではアンドロ ゲン，雌ではエストロゲン）が欠落したために，ACE 活性或は R-A 系機能が低下した結果であ

\section{第67巻 第11号}


ることが考えられる。そこで性ホルモンの PRA, PRCに対する影響及び ACE 活性に対する影響 を合わせて調べた。

雌雄性腺摘除は高血圧を有意阻害したにも拘らず，PRA，PRCには影響がなかった。雌でエス トロゲンは肝蔵での血漿レニン基質合成を促進するが，腎臓でのレニン合成と放出には影響を与え ない(8)。また，雄マウスで唾液腺中のレニンはアンドロゲン依存性を示す ${ }^{18)}$ が，血圧調節機序との 関連は明らかでない。これらのことから，循環血液中のレニンは，性腺摘除による高血圧阻害作用 やカプトプリルの降圧作用の抑制に関与していないと考学られた。

血漿 ACE 活性は性腺摘除の影響および性差が認められなかった。雄 $2 \mathrm{~K} 1 \mathrm{C}$ 高血圧ラットの血漿

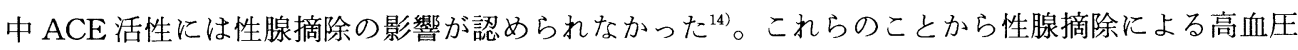
阻害作用やカプトプリルの降圧作用の抑制機序に血漿 ACE 活性は関与していないと考穴られた。 すなわち，血中の ACE はアンドロゲン或はエストロゲンによる血圧調節機序には関与していない ことが明らかとなった。

カプトプリルの降圧効果が見られる低レニン性高血圧モデルで, レニン投与による昇圧と大動脈 中レニン様活性が相関したことから大動脈中レニンは血圧調節機構に重要であることが示唆されて いる ${ }^{19)}$ 。そこで大動脈中のレニン活性に対する性腺摘除の影響を調べた。大動脈中のレニン活性は 卵巣摘出で有意高值を示したが，雄去勢の影響は見られなかった。この機序として，エストロゲン が大動脈レンン活性を抑制し, 卵巣摘出による抑制解除の結果, レニン活性が元進した可能性が推 定される。しかしながら, その機序の詳細は今後検討すべき課題である。また, 性腺摘除による高 血圧阻害作用及びカプトプリルの降圧作用抑制は雄に顕著であったことから大動脈中のレニン活性 は少なくとも，性腺摘除による血圧変化には直接影響を与えないと考えられた。

次に, 大動脈中の ACE 活性に対する性腺摘除の影響を調べた。SHR の大動脈 ACE 活性は WKY より高值を示し ${ }^{20)}$ ，また，2K1C 高血圧ラットでは大動脈や腸間膜動脈中の ACE 活性が高値 を示すことからこれら血管組織で AI から A II への転換がより多く起こり, その高血圧維持の一部 に関与している可能性が報告されている ${ }^{21)}$ 。しかしながら今回, 大動脈中のACE 活性は雌雄性腺 摘除の影響が認められなかった。このことから大動脈中の ACE 活性は性腺摘除によるカプトプリ ルの降圧作用抑制に関与していないと考光られた。以上の結果から, 大動脈中のACE はアンドロ ゲン或はエストロゲンによる血圧調節機序に本質的には関与していないことが推定される。血圧調 節には大動脈以外の末梢血管が重要であることは良く知られている。Okamura らは2K1C 高血圧 ラットで ACE 活性が肺とは異なり，大動脈と腸間膜動脈中で同時期に上昇することを報告してい $ろ^{21)}$ 。このことから少なくとも ACE は腸間膜動脈中でも大動脈中と同様の趨勢を示し，アンドロ ゲン或はエストロゲンによる血圧調節機序に本質的には関与していない可能性が考えられる。

最近, 脳内の R-A 系が高血圧の発症と維持に重要な役割を果たしていることが報告されている がその詳細は不明である。今回，雌雄性腺摘除により間脳のレニン活性が低下した。この変化は性 腺摘除による高血圧阻害作用およびカプトプリルの降圧作用抑制と相関した。カプトプリルは脳内 に移行し ${ }^{22)}$ ，その降圧作用の一部に脳内レニン mRNA が関与している ${ }^{23)}$ 。また，WKY と SHR の 両者にレニンを脳室内投与すると用量依存的に血压は上昇するが，レニンの静脈内投与は血圧に無 影響である ${ }^{24)}$ 。以上から, 脳内レニンは血圧上昇に作用するため雌雄共, 性ホルモンの昇圧作用要 因として，脳内レニン活性上昇を介することが推定された。Metzger らはアンドロゲンが各種組織 内のレニン mRNA レベルを上昇させ, 唾液腺中のレニンがアンドロゲン依存性を示すことを報告 
した ${ }^{25)}$ これは雄の脳内レニンもアンドロゲン依存性を示し，去勢によるアンドロゲン低下の結果， アンドロゲンのレニン活性促進作用が解除され, 間脳のレニン活性が低下する可能性を示している。 一方, 雌でエストロゲンはアンギオテンシノーゲンの合成, 分泌を促進するが, レニンに対しては 見解が一致していない(8)。今回, 雌卵巣摘出で脳内レニン活性が低下したことから卵巣摘出による 間脳のレニン活性低下はエストロゲン低下による可能性が考学られる。以上からアンドロゲン及び エストロゲンは，共に高血圧の発症と維持に促進的に作用していることが推察された。

今回, 雌雄 SHR の高血圧が性腺摘除で有意阻害されることを示した。性腺摘除による高血圧阻 害効果は発症機序の異なる DOCA - 食塩, $2 \mathrm{~K} 1 \mathrm{C}$ や再生副腎性高血圧モデルでも見られる ${ }^{26)}$, 一方, SHR 性腺摘除による高血圧阻害が, 雄テストステロン, 雌エストラジオール各投与で修復される 事実を報告した ${ }^{344)}$ 。このことは高血圧の発症と維持に介入する性ホルモンの作用機序が多様である ことを意味している。これらの各種高血圧に交感神経系と R-A 系は重要な因子である。レニンの 脳室内投与は末梢の交感神経発火頻度を上昇させて昇圧反応を引き起こす ${ }^{24)}$ 。更に, アンドロゲン は交感神経の pre synapse での CA 放出や合成を促進し，一方，エストロゲンは $\alpha$-receptor 感受 性を亢進させる7。これらを考㝋わわるとアンドロゲンとエストロゲンは脳内レニンー交感神経 系を介して血圧に促進的に作用しているのかも知れない。

以上，アンドロゲンとエストロゲンは脳内レニンを上昇させて高血圧の発症と維持に促進的に働 いている可能性が示唆された。

\section{結語}

雌雄 SHR を用いて性腺摘除の末梢，および中枢レニン及び ACE 活性に及汸す影響を調べ，以 下の成績を得た。

1）雌雄 SHR の性腺摘除は共に高血圧を有意阻害した。

2）カプトプリル投与により雌雄 Int, 性腺摘除群共有意に血圧が低下した。このカプトプリルに よる降圧作用は雄去勢により有意抑制, 雌卵巣摘出により抑制傾向を示した。

3）血漿中 ACE 活性は雄去勢で有意高值を示した。PRA, PRC には雌雄共に性腺摘除の影響は 認められなかった。

4）大動脈中 ACE 活性は雌雄共に性腺摘除の影響は認められなかった。大動脈中レニン活性は雌 卵巣摘出で有意高值を示した。

5）間脳 $\mathrm{ACE}$ 活性は雌雄共に性腺摘除の影響は認められなかった。間脳レニン活性は雄去勢で有 意低下, 雌卵巣摘出で低值傾向を示した。以上より, 雌雄共, 性腺摘除による間脳レニン活性低下 が高血圧有意阻害に重要な役割を演じるものと推察される。

\section{謝辞}

稿を終えるにあたり, 御指導, 御校閲をいただきました聖マリアンナ医科大学薬理学教室, 平井 正直主任教授に深甚なる謝意を表します。また, 直接御指導を賜りました増淵美子助教授に深謝致 します。また，御協力をいただきました教室員各位に感謝致します。 


\section{文献}

1) Hypertension Detection and Follow - up Program Cooperative Group: Race, education and prevalence of hypertension. Am. J. Epidemiol., 106: 351-361, 1977.

2) Masubuchi, Y., Kumai, T., Uematsu, A., Komoriyama, K. and Hirai, M.: Gonadectomy-induced reduction of blood pressure in adult spontaneously hypertensive rats. Acta Endocrinology, 101: 154-160, 1982.

3 ) Kumai, T., Masubuchi,Y., Ohno, T., Tanaka, M. and Hirai, M.: Role of testosterone in mechanisms of hypertensionogenesis and in action of antihypertensive agent by the spontaneously hypertensive rats. J. Steroid Biochem., 25: 110S, 1986.

4) Masubuchi, Y., Kumai, T., Ohno, T. and Hirai, M.: Mechanisms of action of estrogen to pressor response and its facilitates the inhibitory action of angiotensin converting enzyme in SHR. Jpn. Heart J., 29: 571, 1988.

5 ) Chevillard, C., Duchene, N., Pasquier, R. and Alexandre, J.: Relation of the centrally evoked pressor effect of angiotensin II to central noradrenaline in the rabbit.

Eur. J. Pharmacol., 58: 203-206, 1979.

6) Unger, T., Badoer, E., Ganten, D., Lang, R.E. and Retting, R.: Brain angiotensin: pathways and pharmacology. Circulation, 77 (Suppl I) I40-I54, 1988.

7) Masubuchi, Y., Kumai, T., Ohno, T., Tanaka, M. and Hirai, M.: Gonadectomy modulate the action of antihypertensive agents in spontaneously hypertensive rats. Jpn. Heart J. , 26: 686, 1985.

8 ) Woods, J.W.: Oral contraceptives and hypertension. Hypertension, 11 (Suppl II): II 11-II 15, 1988.

9 ) Hartle, D.K. and Brody, M.J.: The angiotensin II pressor system of the rat forebrain. Circ. Res., 54: 355-366, 1984.

10) Jonklaas, J. and Buggy, J.: Angiotensin-estrogen central interaction: localization and mechanisms. Brain Res., 326: 239-249, 1985.

11) Mizuno, K., Fukuchi, S. and Kimura, A.: Partial characterization of angiotensin $I$ -converting enzyme of the aorta in rats. Jpn. Heart J., 25: 387-396, 1984.

12) Glowinski, J. and Iversen, L.L.: Regional studies of catecholamines in the rat brain-1. J. Neurochem., 13: 655-669, 1966.

13) Paul, M., Printz, M.P., Harms, E., Unger, T., Lang, R. and Ganten, D.: Localization of renin and converting enzyme in nerve endings of rat brain. Brain Res., 334: 315-324, 1985.

14) Mizuno, K., Hashimoto, S., Ojima, M., Kunii, N., Tani, M., Niimura, S., Watari, H. and Fukuchi, S.: Immunoreactive renin in human brain: distribution and properties. Jap. Circ. J. , 49: 1005-1011, 1985.

15) Lowry, O.H., Rosebrough, N.J., Farr, A.L. and Randall, R.J.: Protein measurement with folin phenol reagent. J. Biol. Chem., 193: 265-275, 1951.

16) Chen, Y. and Meng, Q.: Sexual dimorphism of blood pressure in spontaneously 
hypertensive rats is androgen dependent. Life Sci., 48: 85-96, 1991.

17) Masubuchi, Y., Kumai, T., Ohno, T., Tanaka, M., Watanabe, M., Suetsuna, M. and Hirai, M.: Gonadectomy induced reduction of blood pressure in the two-kidney one clip (2K1C) rat. Jap. J. Pharmacol., 40 (Suppl): 71P, 1986.

18) Wilson, C.M., Cherry, M., Taylor, B.A. and Wilson, J.D.: Genetic and endocrine control of renin activity in the submaxillary gland of the mouse. Biochem. Genet., 19: 509-523, 1981.

19) Swales, J.D., Loudon, M., Bing, R.F. and Thurston, H.: Renin in the arterial wall. Clin. Exp. Hypertens., (A) 5: 1127-1136, 1983.

20) Mizuno, K., Hata, S. and Fukuchi, S.: Effect of sodium intake on angiotensin converting enzyme activity of aorta in rats. Clin. Sci., 61: 249-251, 1981.

21) Okamura, T., Miyazaki, M., Inagami, T. and Toda, N.: Vascular renin-angiotensin system in two-kidney, one clip hypertensive rats. Hypertension, 8: 560-565, 1986.

22) Tada, M., Fukamizu, A., Seo, M.S., Takahashi, S. and Murakami, K.: Renin expression in the kidney and brain is reciprocally controlled by captopril. Biochem. Biophys. Res. Comm., 159: 1065-1071, 1989.

23）亘理裕昭：脳内レニンの高血圧に対する成因的意義. 日内泌誌，65：66-78，1989.

24) Kawasaki, H., Takasaki, K. and Furukawa, T.: Exaggerated pressor response to centrally administered renin in freely moving, spontaneously hypertensive rats. Eur. J. Pharmacol., 138: 351-357, 1987.

25) Metzger, R., Wagner, D., Takahashi, S., Suzuki, F., Lindpaintner, K. and Ganten, D. : Tissue renin-angiotensin systems aspects of molecular biology and pharmacology. Clin. Exp. Hypertens., (A) 10: 1227-1238, 1988.

26) Hirai, M., Masubuchi, Y., Kumai, T. and Ohno, T.: Indispensable role of gonad in hypertensinogenesis (such as SHR, 2K1C, 1K-DOCA salt and adrenal regenerating rats). Jpn. Heart J. , 27: 585, 1986.

（受付日：' 91.4 .22 特揭）

（採択日：'91. 8.23） 